\title{
Unexpected genetic structure of mussel populations in South Africa: indigenous Perna perna and invasive Mytilus galloprovincialis
}

\author{
G. I. Zardi ${ }^{1, *}$, C. D. McQuaid ${ }^{1}$, P. R. Teske ${ }^{1,2}$, N. P. Barker ${ }^{2}$ \\ ${ }^{1}$ Department of Zoology and Entomology, and ${ }^{2}$ Molecular Ecology and Systematics Group, Botany Department, \\ Rhodes University, Grahamstown 6140, South Africa
}

\begin{abstract}
Genetic structure of sedentary marine organisms with planktonic larvae can be influenced by oceanographic transport, larval behaviour and local selection. We analysed the population genetic structure (based on mtDNA) of the invasive mussel Mytilus galloprovincialis and the indigenous mussel Perna perna along the southern African coastline. Low genetic divergence of M. galloprovincialis confirms its recent arrival in South Africa. In contrast, the genetic structure of $P$. perna revealed strong divergence on the south-east coast, forming a western and an eastern lineage. The distribution of the 2 lineages is extraordinary. They overlap for ca. $200 \mathrm{~km}$ on the southeast coast, and the western lineage includes animals occurring on either side of a $1000 \mathrm{~km}$ break in distribution across the Benguela upwelling system. In cluster analyses, animals on the south coast grouped with others $1000 \mathrm{~s}$ of $\mathrm{km}$ to the west, rather than with those only $200 \mathrm{~km}$ to the east. This genetic disjunction may be caused by the south-flowing Agulhas Current preventing larval dispersal, or by different selective forces acting on local populations. M. galloprovincialis spread eastward along the south coast for $15 \mathrm{yr}$, but its range extension has virtually ceased in the region of genetic disjunction in P. perna, again indicating an oceanographic barrier to larval dispersal or selection driven by sharp gradients in environmental conditions. The results suggest that local selection can produce genetic structure opposite to that predicted by oceanographic data and that determining the population structure of indigenous species with similar larval dispersal can help us understand domain expansion of invading species.
\end{abstract}

KEY WORDS: Mytilus galloprovincialis · Perna perna · Invasion · Biogeographic region · Currents • mtDNA

\section{INTRODUCTION}

An important factor influencing the dynamics of a biological invasion is the ability of the invader to disperse, thus spreading from the founder population and extending its domain. The dispersal potential of seeds, spores influences large-scale patterns of distribution and geographic ranges of sedentary organisms (Perron \& Kohn 1985, Richmond 1987, Scheltema 1989, Gaines \& Bertness 1992, Emlet 1995). Marine species possessing pelagic larvae have the potential for a high degree of connectivity among local popula- tions. This connectivity is potentially of considerable importance and reflects the magnitudes of immigration and emigration (Sale 1991, Caley et al. 1996). Gene flow (via larval dispersal) can provide information on connectivity among populations (Avise et al. 1987, Burton 1998). In this study, we explored the population genetic structure of the 2 dominant intertidal mussel species in South Africa, the invasive Mytilus galloprovincialis and the indigenous Perna perna, over the entire South African and southern Namibian coastlines, and we found unexpected population structure. 
Mytilus galloprovincialis is invasive in many parts of the world and is the most successful marine invader in South Africa (Grant \& Cherry 1985, Branch \& Steffani 2004, Robinson et al. 2005). This European species arrived in South Africa at Saldanha Bay (Fig. 1; Site 14, $150 \mathrm{~km}$ north of the Cape of Good Hope) in the early 1970s, probably with shipping (Grant \& Cherry 1985). Soon after its first detection, it spread to the north at an average rate of $115 \mathrm{~km} \mathrm{yr}^{-1}$ and to the south at about $25 \mathrm{~km} \mathrm{yr}^{-1}$ (Hockey \& van Erkom Schurink 1992). It is now the dominant intertidal mussel from the Cape of Good Hope in South Africa to Lüderitz in southern Namibia (Fig. 1; Griffiths et al. 1992, Hockey \& van Erkom Schurink 1992, Branch \& Steffani 2004). The European mussel stopped its progression in central Namibia where, presumably, the subtropical conditions characterising northern Namibia (Shannon 1985) represent the limits of its tolerance. M. galloprovincialis has spread from the Cape of Good Hope eastwards to within $20 \mathrm{~km}$ west of East London (Fig. 1; McQuaid \& Phillips 2000, Robinson et al. 2005). In the last $10 \mathrm{yr}$, its expansion on the south coast has virtually ceased, and it may have reached its biogeographic limit (Robinson et al. 2005). As on the Namibian coast,

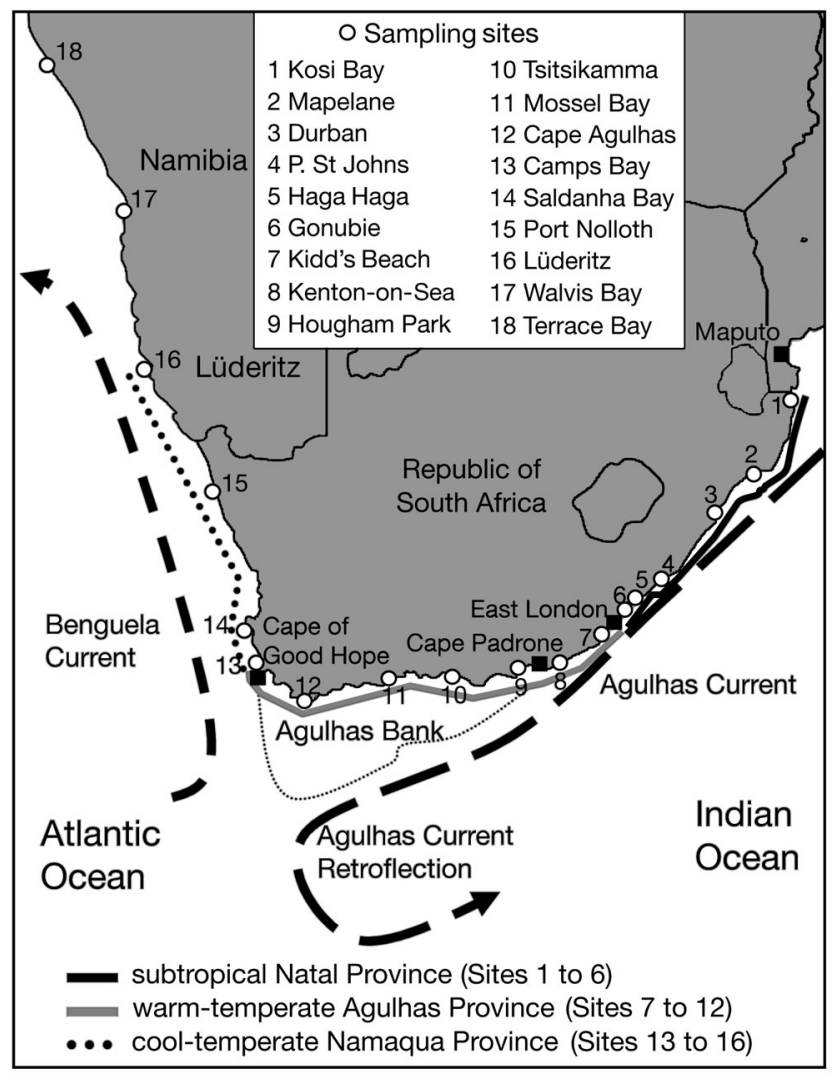

Fig. 1. Sampling locations for Mytilus galloprovincialis and Perna perna, and location of Agulhas and Benguela Currents. Biogeographical provinces according to Emanuel et al. (1992) this limit could be explained by the subtropical conditions found north of East London, indicating that $M$. galloprovincialis invasion in South Africa conforms to the antitropical distribution pattern typical of Mytilus spp. (Hilbish et al. 2000).

Perna perna is abundant along the entire east coast of South Africa, and on the south coast of South Africa it shows partial habitat segregation with Mytilus galloprovincialis (Bownes \& McQuaid 2006), which it competitively excludes from the low shore (Rius \& McQuaid 2006). The cold waters of the Benguela upwelling system limit $P$. perna distribution north of the Cape of Good Hope, and it is absent from there to Lüderitz in southern Namibia (Fig. 1), a distance of approximately $1000 \mathrm{~km}$. P. perna re-appears in Namibia and extends along the west coast of Africa to the Mediterranean Sea as far as the Gulf of Tunis (van Erkom Schurink \& Griffiths 1990).

Both species have planktotrophic larvae that disperse in the water column for a period of feeding and growth, before settling to the substratum and being recruited into an adult population. Given the relatively long period of larval duration, both species have the potential for high dispersal rates. However, several studies have shown discrepancies between the potential and the realised dispersal of larvae (Palumbi 1994, Todd 1998), and on the South African coast, dispersal scales of Mytilus galloprovincialis larvae are limited to 10s of km (McQuaid \& Phillips 2000). Such discrepancies are mainly due to the influence of oceanographic conditions on larval behaviour, to reproductive timing and to the availability of suitable habitat in terms of both biotic and abiotic factors (Shanks 1995, Todd 1998, Shanks \& Brink 2005). Consequently, we would expect the genetic structure of populations of species with planktonic larvae to be strongly shaped by prevailing oceanographic conditions.

The primary oceanographic influence on the east and south coasts of South Africa is the Agulhas Current. This warm current is about 60 to $100 \mathrm{~km}$ wide and flows to the southwest along the eastern seaboard of South Africa (from $27^{\circ} \mathrm{S}$ to $40^{\circ} \mathrm{S}$ ) at rates of 10 to $20 \mathrm{~km} \mathrm{~d}^{-1}$, following the $200 \mathrm{~m}$ isobath of the continental shelf from Maputo in Mozambique to the tip of the Agulhas Bank in South Africa (Fig. 1; Lutjeharms 1998, 2004). The inshore thermal front of this current varies geographically and in time, and may alter patterns of along-shelf larval dispersal. It usually lies 14 to $38 \mathrm{~km}$ offshore, but it can flow onto the coast at 0 to $1 \mathrm{~km}$ offshore (Goschen \& Schumann 1990). In contrast, the coastal environment of western South Africa, Namibia and southern Angola is profoundly influenced by the Benguela Current, which flows from the Cape of Good Hope northwards to Lüderitz, where the main flow is deflected away from the coast to the northwest (Peter- 
son \& Stramma 1991, Wedepohl et al. 2000; Fig. 1). The Benguela Current is characterised by Ekman-driven coastal upwelling. Intense and consistent upwelling off Lüderitz $\left(27-28^{\circ} \mathrm{S}\right)$ separates the Northern Benguela from the Southern Benguela and creates a semipermanent environmental barrier (Boyd \& Cruickshank 1983, Agenbag \& Shannon 1988). Perna perna is missing from the entire Benguela region along $1000 \mathrm{~km}$ of coast.

Genetic differentiation can occur among populations of marine organisms with high dispersal potential due to local differences in selection (Johnson \& Black 1984, Hedgecock 1986, Bertness \& Gaines 1993). The South African coastline covers a wide range of climatic and oceanic conditions and can be divided into biogeographic regions that support a great diversity of algae and animals. Based on an analysis of rocky shore invertebrates, Emanuel et al. (1992) divided the South African coast into 3 zoogeographic regions (Fig. 1): from Lüderitz in Namibia to the Cape of Good Hope (cool-temperate Namaqua Province); from the Cape of Good Hope to East London (warm-temperate Agulhas Province); from East London to Mozambique (subtropical Natal Province).

In this study, we used mitochondrial DNA (mtDNA) to investigate the genetic structure of Mytilus galloprovincialis and Perna perna populations along the South African and Namibian coastline. Specifically, we wished to compare an invasive and an indigenous species and to examine the effects on their genetics of both biogeography and the oceanographic conditions dominating the nearshore environment.

\section{MATERIALS AND METHODS}

Sampling, DNA extraction, amplification and sequencing. Populations of Mytilus galloprovincialis and Perna perna were sampled at 11 and 14 sites, respectively, along the Namibian and South African coasts (10 individuals from each population; Fig. 1). Mussels were opened in the laboratory, and a piece of gonad tissue was examined under a microscope to determine the sex of the animal by the presence of eggs or sperm. Because of doubly uniparental inheritance, only female individuals were used in this study. Whole genomic DNA was extracted from approximately $1 \mathrm{~mm}^{3}$ of gonad tissue (attached to the mantle) using a standard phenol-chloroform extraction method, and samples were then re-dissolved in $50 \mu \mathrm{l}$ water. The primers LCOI 1490 (5'-GGT CAA CAA ATC ATA AAG ATA TTG-3') and HCO 2198 (5'-TAA ACT TCA GGG TGA CCA AAA AAT CA-3') (Folmer et al. 1994) were used in a polymerase chain reaction (PCR) to amplify a portion of the mitochondrial cytochrome oxidase subunit I gene (mtDNA COI). Amplifications were performed in a $100 \mu \mathrm{l}$ solution containing 10 to $100 \mu \mathrm{g}$ of DNA, $0.4 \mu \mathrm{M}$ of each primer, $5 \mu \mathrm{l}$ of Qiagen PCR buffer, $200 \mu \mathrm{M}$ of each dNTP, and 2.5 U of Taq DNA polymerase (Qiagen). The PCR cycling profile comprised an initial denaturation step at $94^{\circ} \mathrm{C}$ for $2 \mathrm{~min}, 35$ cycles of denaturation at $94^{\circ} \mathrm{C}$ for $60 \mathrm{~s}$, annealing at $54^{\circ} \mathrm{C}$ for $60 \mathrm{~s}$, extension at $72^{\circ} \mathrm{C}$ for $90 \mathrm{~s}$, and a final extension at $72^{\circ} \mathrm{C}$ for $5 \mathrm{~min}$. PCR products from each individual were purified with a Qiaquick gel extraction kit (Qiagen) and cyclesequenced in both forward and reverse direction with the same primers used in the amplification, using a BigDye ${ }^{\circledR}$ Terminator v3.1 Cycle Sequencing kit (Applied Biosystems) and sequenced on an ABI 3100 genetic analyser.

Data analysis. DNA sequences were translated into amino acid data using the standard invertebrate mitochondrial genetic code to verify their mitochondrial origin. We are confident of the origin because: (1) there was at least one reading frame with no stop codon, (2) all translated sequences matched with published records of COI sequences in GenBank, and (3) no variable nucleotide positions consistently showing double peaks were encountered in chromatograms, as might be expected in the case of nuclear pseudogenes.

PAUP* version 4.0b10 (Swofford 2002) was used to construct neighbour-joining trees using the most suitable model of sequence evolution for each species, as suggested by the Akaike Information Criterion (AIC), as implemented in the program MODELTEST 3.06 (Posada \& Crandall 1998). In addition, parsimony analyses were done using PAUP* version $4.0 \mathrm{~b} 10$ (Swofford 2002). Heuristic tree searches were performed using 1000 random sequence additions and tree bisection-reconnection (TBR) branch swapping. Nonparametric bootstrap values (Felsenstein 1985) were calculated using 1000 replicates and 10 random taxon additions.

A triangular matrix of p-distances among Perna perna individuals was generated using PAUP* version 4.0b10 (Swofford 2002) and imported into Excel to calculate mean intra- and inter-lineage average sequence divergence.

Isolation by distance. Mitochondrial DNA lineages identified using genealogical reconstructions were examined for evidence of isolation by distance by testing for correlation between genetic and geographic distance (Slatkin 1993). ARLEQUIN version 2.001 (Schneider et al. 2000) was used to calculate $\phi_{\mathrm{ST}}$ values (as a measure of sequence divergence among haplotypes; Excoffier et al. 1992) among populations associated with specific lineages. The geographic distance between populations was measured as the shortest continuous water-surface distance. The relationship 
between genetic differentiation and geographical distance was assessed by performing Mantel tests using the program MANTEL for Windows version 1.16 (Cavalcanti 2005). The significance of the Mantel statistic $Z$ is tested by a permutation procedure in which values in 1 data matrix are randomly reshuffled (20000 permuted data-sets were created).

\section{RESULTS}

\section{Sequence characteristics}

Sequence data (400 bp) from 110 and 140 individuals of Mytilus galloprovincialis and Perna perna, respectively, were analysed. In the case of M. galloprovincialis, 29 nucleotide sites were polymorphic and 18 were parsimony informative; a total of 21 haplotypes was identified. $P$. perna had 50 unique haplotypes and 58 polymorphic sites, 27 of which were parsimony informative. Haplotypes of both species have been deposited in GenBank (P. perna: DQ351427DQ351476, M. galloprovincialis: DQ351477-DQ351497).

\section{Phylogeographical patterns}

The neighbour-joining tree of Perna perna recovered 2 distinct lineages (Fig. 2). One lineage included samples from Terrace Bay to Haga Haga (i.e. from the Namibian coast to the southeast South African coast). Samples of the other lineage originated from Kosi Bay to Kentonon-Sea (i.e. east coast to southeast coast). The distributions of the 2 $P$. perna lineages thus overlap for about $200 \mathrm{~km}$ between Haga Haga and Kenton-on-Sea on the southeast coast (Fig. 2). Average withinlineage sequence divergences were 1.1 and $1.0 \%$ for the eastern and western lineage, respectively. Average sequence divergence between the 2 lineages was $2.9 \%$.

Perna perna showed greater nucleotide diversity than Mytilus galloprovincialis. Haplotypes 1 and 2 were the most common in populations from the eastern lineage (east coast) and the western lineage (south and west coasts), respectively (Fig. 3). Haplotype 1 was never found in the Namibian populations, and west of Gonubie it was found in only 2 individuals (1 each from Kenton-on-Sea and Kidd's Beach; Fig. 3). Haplotype 2 was the most common haplotype on the south coast and was also sampled once in Walvis Bay. It was never found farther east than Kidd's Beach (Fig. 3). Haplotype 3 was most common on the south coast, but was also sampled at Terrace Bay in Namibia and Haga Haga. Haplotypes restricted to a single site (private haplotypes) were found at all locations, and were more frequent in the western lineage than in the eastern lineage. Note that a greater sample size could have changed the proportion of

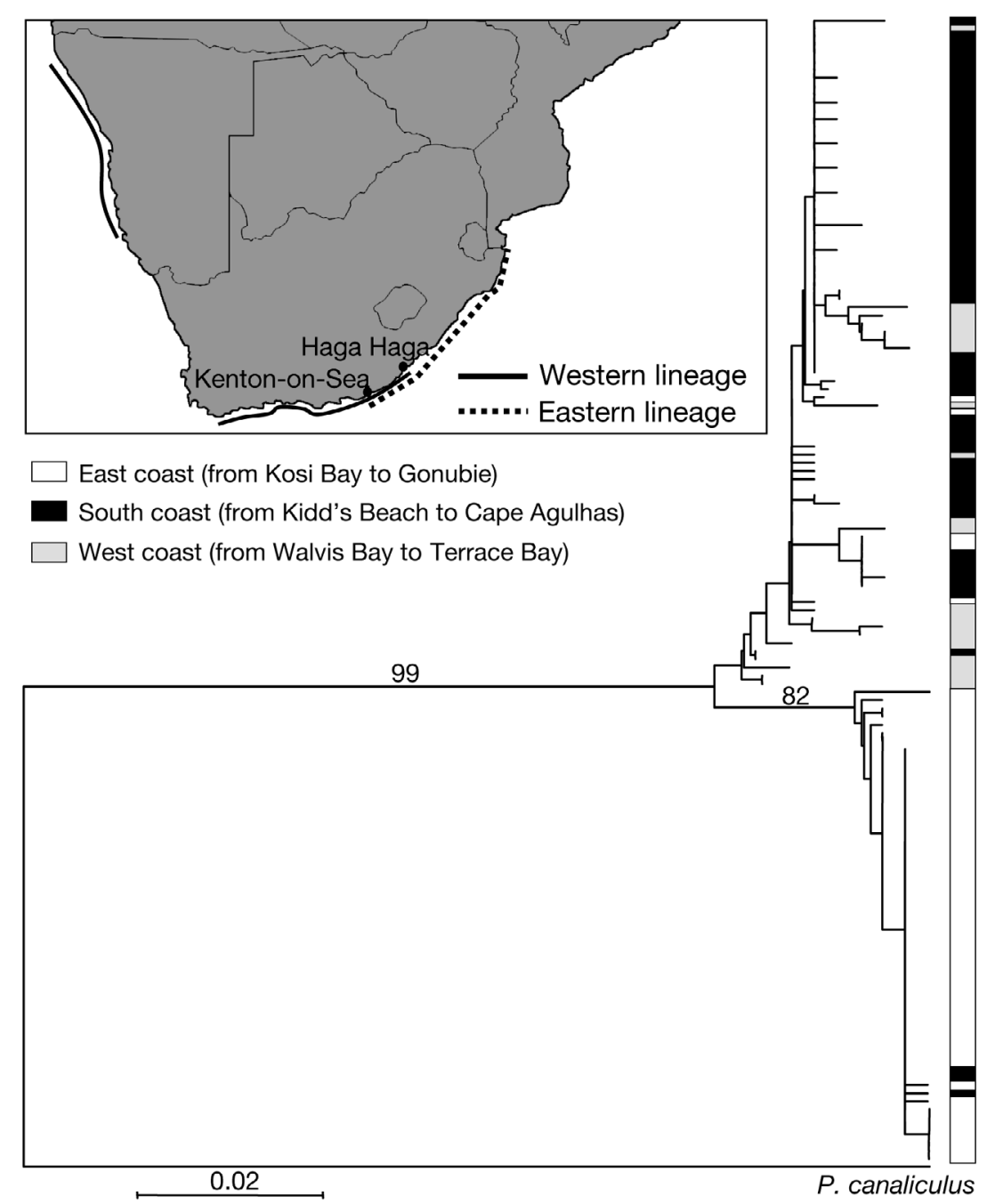

Fig. 2. Perna perna. Geographic distribution pattern of the mtDNA lineages and neighbour-joining phylogram based on sequences from cytochrome oxidase I (COI). The tree was rooted using a female $P$. canaliculus as an outgroup. Parsimony bootstrap values from 1000 bootstrap replications were added to some branches. Model selected: $\operatorname{TrN}$ (Tamura \& Nei 1993). Gamma distribution parameter $(\gamma)$ estimated in MODELTEST was 0.22. See Fig. 1 for location codes 

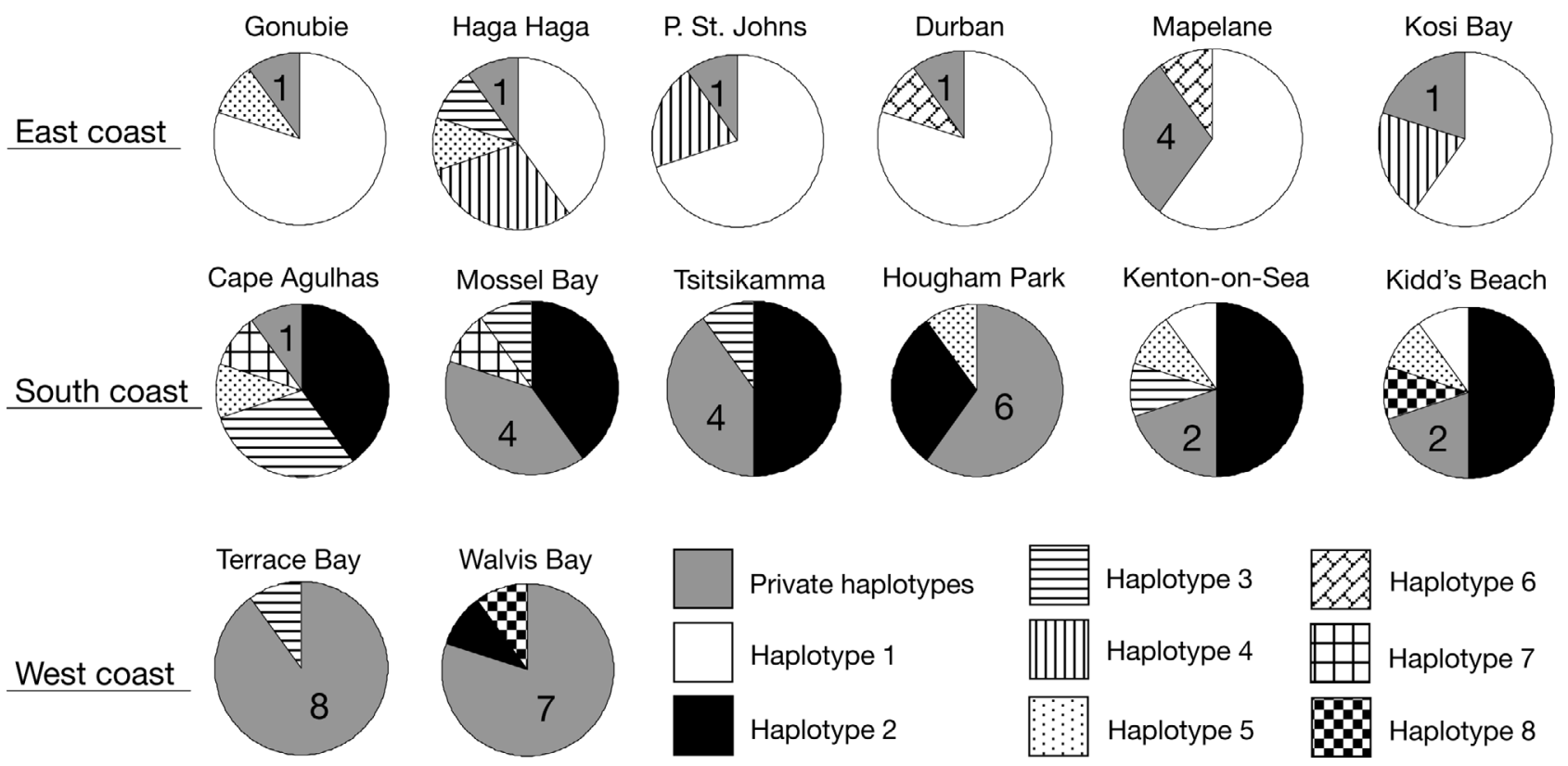

Haplotype 3

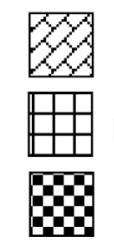

Haplotype 6

Haplotype 4

Haplotype 7

Haplotype 5

Haplotype 8

Fig. 3. Perna perna. Haplotype frequencies at each sampling site. For private haplotypes, the number of haplotypes is given

private haplotypes. The highest frequency of private haplotypes (80 to $90 \%$ ) was found in the 2 Namibian populations (Fig. 3). Haplotype 4 was private to the east coast. As with Haplotype 1, Haplotype 5 was sampled on both the south and the east coasts. Haplotype 6 was private to Mapelane and Durban. Haplotype 10 was private to Cape Agulhas and Mossel Bay. Haplotype 11 was only found twice, in Walvis Bay and Kidd's Beach, which are 1000s of km apart (Fig. 1).

The neighbour-joining tree of Mytilus galloprovincialis recovered only 1 lineage with a distribution from Terrace Bay to Kenton-on-Sea, i.e. the whole of its distribution range (Fig. 4). Low haplotype diversity characterised M. galloprovincialis. Haplotype 1 was the most common at all sites (Fig. 5). Private haplotypes were found at all locations, except at 3 sites from the west coast (Terrace Bay, Lüderitz, Saldanha Bay). Haplotype 3 was private to Mossel Bay and Cape Agulhas. Haplotypes 4, 5 and 6 were all private to the Namibian and South African west coasts.

\section{Isolation by distance}

A significant correlation between pairwise $\phi_{\mathrm{ST}}$ values and geographic distance was only found for the western lineage of Perna perna (Table 1). However, when the 2 Namibian populations were excluded, the relationship was no longer significant.
Fig. 4. Mytilus galloprovincialis. Neighbour-joining phylogram based on sequences from cytochrome oxidase I (COI). The tree was rooted using a male $M$. edulis as an outgroup. Parsimony bootstrap values from 1000 bootstrap replications were added to some branches. Model selected: HKY+ G (Hasegawa et al. 1985). Gamma distribution parameter $(\gamma)$ estimated in MODELTEST was 0.335

South coast (from Kidd's Beach to Cape Agulhas)

West coast (from Walvis Bay to Terrace Bay)

88

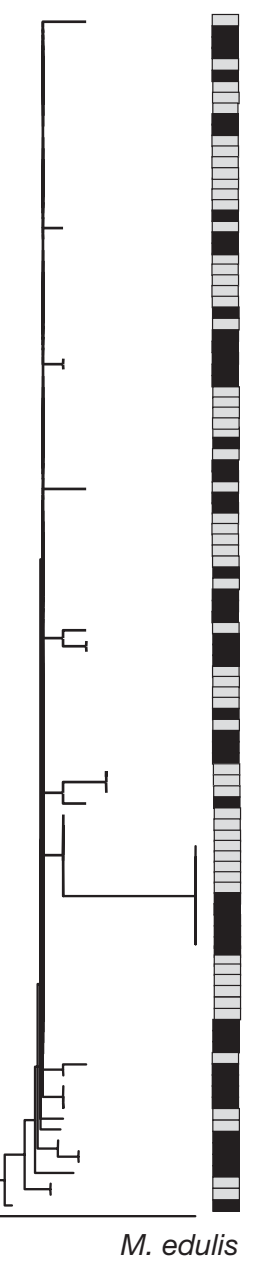




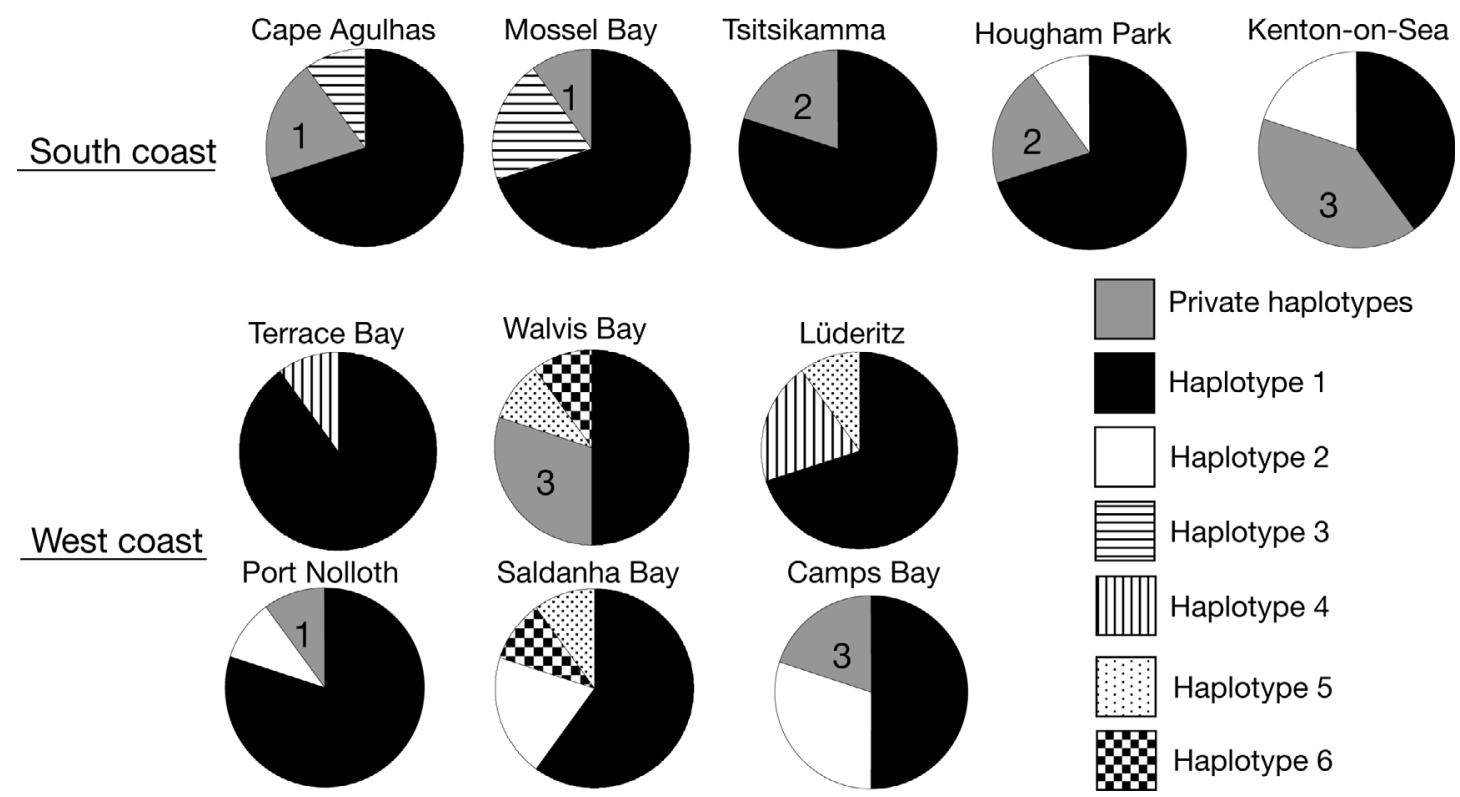

Fig. 5. Mytilus galloprovincialis. Haplotype frequencies at each sampling site. For private haplotypes, the number of haplotypes is given

\section{DISCUSSION}

Mitochondrial DNA sequences of Perna perna indicate a strong phylogeographic break on the east coast between Kidd's Beach and Gonubie, a distance of about $40 \mathrm{~km}$. A previous study showed that there was essentially no allozyme-frequency differentiation in $P$. perna along the whole South African coastline (Grant et al. 1992). The only difference in allozyme frequencies was found at the western edge of the geographic distribution of $P$. perna on the southwest coast. We could not find $P$. perna on the western shore of the

Table 1. Results of Mantel tests on matrices of genetic differentiation among populations (pairwise $\Phi_{\mathrm{ST}}$ using p-distances) and geographic distance of the Mytilus galloprovincialis mtDNA lineage, and of the Perna perna Western lineage, Eastern lineage and Western lineage excluding the 2 Namibian populations. $\mathrm{r}=$ Pearson product-moment correlation (shown instead of the Mantel $Z$ statistic for simplicity of interpretation), $t=$ approximate Mantel $t$-test statistic, $\mathrm{p}=$ probability that random $Z<$ observed $Z$. Significant value in bold

\begin{tabular}{|lrrl|}
\hline & $\mathrm{r}$ & \multicolumn{1}{c|}{$t$} & \multicolumn{1}{c|}{$\mathrm{p}$} \\
\hline Perna perna & & & \\
Western & -0.358 & -2.252 & $\mathbf{0 . 0 1 2 2}$ \\
Western excluding Terrace & 0.202 & -0.966 & 0.833 \\
$\quad$ Bay and Walvis Bay & & & \\
Eastern & 0.192 & 0.850 & 0.8 \\
Total (Western + Eastern) & -0.141 & -1.354 & 0.09 \\
Mytilus galloprovincialis & & & \\
$\quad$ Total & -0.052 & -0.374 & 0.35 \\
\hline
\end{tabular}

Cape Peninsula, which seems to confirm the suggestion of Grant et al. (1992) that populations are not selfsustaining, but originate by chance recruitment from more eastern subpopulations and are subject to dramatic changes in population structure. Grant et al. (1992) collected an additional sample at Swakopmund (Namibia), showing the absence of alleles unique to the Namibian samples, and indicating close genetic affinity to South African populations.

Our study shows that some haplotypes occurring in the South African samples are also present in the Namibian samples, suggesting a certain level of gene flow between the 2 regions. It is unlikely that Perna perna larvae are now able to connect Namibian and South African populations by dispersing through the cold waters of the Benguela upwelling system. However, the Pleistocene or Quaternary oceanic warming (Shannon 1985, Thackeray \& Herbert 1991) could have allowed colonisation of this stretch of coast and dispersal through the present distribution gap. Mantel test results reported here indicate that the gap of about $1000 \mathrm{~km}$ in distribution of $P$. perna between Cape Agulhas and Walvis Bay on the west coast results in significant isolation by distance. Nevertheless, $P$. perna from Kenton-on-Sea group with those from Namibia, $2000 \mathrm{~km}$ away, rather than with those from Haga Haga, $200 \mathrm{~km}$ to the east. Several competing hypotheses could explain the separation of the 2 lineages in Perna perna:

(1) Physical isolation, resulting in reduced gene flow. The Agulhas Current lies relatively close inshore in the overlap region and could act as a barrier to the disper- 
sal of larvae from west to east, but this does not explain the lack of dispersal in the opposite direction. Nor does it accord with the fact that $P$. perna on either side of the Benguela System, which forms a formidable barrier to dispersal, share a dominant haplotype absent from the eastern lineage.

(2) Recent secondary contact between 2 lineages that have been separated for a long period, though again it is difficult to identify possible mechanisms of isolation.

(3) Differential selection. Many studies have investigated the limits of the marine biogeographic regions of South Africa using different organisms (Stephenson \& Stephenson 1972, Day 1981, Potter et al. 1990, Prochazka 1994, Turpie et al. 2000). The general agreement is that the boundary between the warm temperate region and the subtropical region lies on the southeast coast (Harrison 2000). Environmental factors characterising these areas may subject $P$. perna populations to different selective forces leading to genetic divergence. To produce such a sharp discontinuity, such selective forces would have to be very powerful.

Grant \& Cherry (1985) examined shells taken from prehistoric shell middens and the shell collection at the Zoology Department of the University of Cape Town and concluded that the introduction of Mytilus galloprovincialis to southern Africa took place within the previous 20 yr. The low haplotype diversity over the total geographic range of $M$. galloprovincialis in South Africa confirms its recent arrival. After spreading along the south coast, it seems that $M$. galloprovincialis has reached its biogeographic limit near Kidd's Beach in the East London area (McQuaid \& Philips 2000, Robinson et al. 2005), that is, in the area of phylogenetic discontinuity in Perna perna. M. galloprovincialis is highly invasive in many parts of the world and is well adapted to a wide range of environmental factors, including temperature (Branch \& Steffani 2004). Invasions frequently constitute rapid evolutionary events (Reznick \& Ghalambor 2001), resulting in populations that are genetically dynamic over both space and time. Invasive species are often assumed to penetrate habitat boundaries through their broad tolerance (eurytolerance) or phenotypic plasticity (Ricciardi \& MacIsaac 2000, Wolff 2000, Reid \& Orlova 2002). However, certain populations cannot tolerate or acclimatise to the full range of environmental factors occupied by the species complex, but instead experience strong selection when invading new habitats (Lee 1999, Lee \& Petersen 2003). Consequently, the environmental conditions prevailing in the different biogeographic regions of South Africa could exert strong selection on the physiological tolerance and performance of M. galloprovincialis during habitat invasion. Another possible explanation for the apparent drop in rate of spread near East London is that M. galloprovincialis, under east coast environmental conditions, is a weaker competitor in the interaction with the eastern lineage of $P$. perna, which excludes $M$. galloprovincialis from the low shore in the Kenton-on-Sea area (Rius \& McQuaid 2006), and it is possible that farther east, weaker performance of $M$. galloprovincialis, coupled with stronger performance of a different genetic lineage of $P$. perna, excludes the invasive species not only from the lower shore but from the entire intertidal habitat.

The west coast of South Africa is influenced by the upwelling of cool, nutrient-rich water, and Perna perna is presumably excluded from this region by low water temperatures. Strong perennial upwelling off Lüderitz effectively separates the Northern Benguela from the Southern Benguela. A northwesterly moving tongue of upwelled, turbulent water acts as a semi-permanent environmental barrier to the longshore transport of pelagic fish eggs and larvae (O'Toole 1977, Agenbag 1980, Boyd \& Cruickshank 1983, Agenbag \& Shannon 1988). However, this oceanographic barrier did not prevent the expansion of Mytilus galloprovincialis from Saldana Bay, and it was able to rapidly colonise this stretch of coast as far as central Namibia (Branch \& Steffani 2004).

High levels of genetic divergence, either within or among populations of marine taxa, are not uncommon (e.g. Quattro et al. 2001, Tarjuelo et al. 2001, Baker et al. 2003, Papakostas et al. 2005, Remerie et al. 2006), and they have often been related to the presence of cryptic species. Perna perna mtDNA sequence data indicate a continuous coastal distribution with cryptic phylogeny, with a $2.9 \%$ sequence divergence between the eastern and western lineages. Past work has provided conflicting perspectives on the likely efficacy of mtDNA markers in delineating species boundaries. Some studies, including extensive analyses of GenBank data, have indicated that even closely related species ordinarily show marked mitochondrial divergence (Avise \& Walker 1999, Hebert et al. 2003). However, others suggest that mtDNA markers will often encounter problems in species resolution (Funk \& Omland 2003, Lipscomb et al. 2003, Mallet \& Willmott 2003). For example, Will \& Rubinoff (2004) concluded that nearly one-fourth of all animal species fail the test of mitochondrial monophyly. Future studies could be important in determining whether there are previously unnoticed phenotypic differences between the 2 $P$. perna mtDNA lineages, but only breeding experiments and the use of nuclear gene markers would show if the 2 lineages are reproductively isolated. Transplant experiments, i.e. moving different haplotypes between regions, would help us to understand whether adaptation to different environmental condi- 
tions is evident. In addition, mtDNA sequences of $P$. perna larvae sampled in the south, warm-temperate and eastern subtropical biogeographic regions would help to determine whether the Agulhas Current operates as an oceanographic barrier, physically limiting dispersal, or if the genetic divergence results from the selective action of different environments.

The invasion of South Africa by Mytilus galloprovincialis has had major ecological consequences for the structure of intertidal communities, including the replacement of indigenous species and effects at higher trophic levels. After initially spreading rapidly, its rate of expansion has dramatically decreased. It now has an antitropical distributional range typical of the $M$. edulis group (i.e. M. edulis, M. galloprovincialis, $M$. trossulus). This supports the prediction that this invasive species has reached its limits in southern Africa and that it will not expand further.

Hydrography is often critical to gene flow among populations, but the patterns identified here are not those that would be predicted by consideration of hydrodynamics alone. The Agulhas Current flows very close inshore in the region of overlap between our lineages, and this could plausibly minimise gene flow by advecting larvae away from the coast. However, this effect would have to be both powerful and continuous, as mussels do not breed in the same month each year, and we must reconcile this with the fact that Perna perna on either side of a semi-permanent upwelling cell near Lüderitz in Namibia belong to the same lineage. Indeed, the distribution of haplotypes is antithetical to that expected on the basis of oceanographic data alone. Whatever the mechanism producing the patterns seen in $P$. perna genetics, our results suggest that the factors responsible for the phylogeographic break in P. perna populations also limit the distribution of Mytilus galloprovincialis, so that defining the population genetic structure of an indigenous species can be important in determining the presence of environmental barriers that could limit the demographic expansion of an invasive species with similar potential dispersal.

Acknowledgements. This study was supported by the National Research Foundation of South Africa. We are grateful to K. R. Nicastro, K. Sink, J. Basson, T. Robinson, J. Harris and B. Currie for helping with the sampling.

\section{LITERATURE CITED}

Agenbag JJ (1980) General distribution of pelagic fish off South West Africa as deduced from aerial fish spotting (1971-1975 and 1977) and as influenced by hydrology. Fish Bull S Afr 13:55-67

Agenbag JJ, Shannon LV (1988) A suggested physical explanation for the existence of a biological boundary at $24^{\circ} 30^{\prime} \mathrm{S}$ in the Benguela system. S Afr J Mar Sci 6: $119-132$

Avise JS, Walker D (1999) Species realities and numbers in sexual vertebrates: perspectives from an asexually transmitted genome. Proc Natl Acad Sci USA 96:992-995

Avise JC, Arnold J, Ball RM, Bermingham E, Lamb T, Neigel JE, Reeb CA, Saunders NC (1987) Intraspecific phylogeography: the mitochondrial DNA bridge between population genetics and systematics. Annu Rev Ecol Syst 18:489-522

Baker AM, Bartlett C, Bunn SE, Goudkamp K, Sheldon F, Hughes JM (2003) Cryptic species and morphological plasticity in long-lived bivalves (Unionoida: Hyriidae) from inland Australia. Mol Ecol 12:2707-2717

Bertness M, Gaines SD (1993) Larval dispersal and local adaptation in acorn barnacles. Evolution 47:316-320

Bownes SJ, McQuaid CD (2006) Will the invasive mussel Mytilus galloprovincialis Lamarck replace the indigenous Perna perna L. on the south coast of South Africa? J Exp Mar Biol Ecol 338:140-151

Boyd AJ, Cruickshank RA (1983) An environmental basin model for west coast pelagic fish distribution. S Afr J Sci 79:150-151

Branch GM, Steffani CN (2004) Can we predict the effects of alien species? A case-history of the invasion of South Africa by Mytilus galloprovincialis (Lamarck). J Exp Mar Biol Ecol 300:189-215

Burton RS (1998) Intraspecific phylogeography across the Point Conception biogeographic boundary. Evolution 52: 734-745

Caley MJ, Carr MH, Hixon MA, Huges TP, Jones GP, Menge BA (1996) Recruitment and the local dynamics of open marine populations. Annu Rev Ecol Syst 27:477-500

Cavalcanti MJ (2005) MANTEL for Windows version 1.16 test for association between two symmetric distance matrices with permutation iterations. Departamento de Vertebrados, Museu Nacional do Rio de Janeiro, Brazil. Available at http://life.bio.sunysb.edu/morph/

Day JH (1981) Summaries of current knowledge of 43 estuaries in southern Africa. In: Day JH (ed) Estuarine ecology with particular reference to southern Africa. AA Balkema, Cape Town, p 251-329

Emanuel BP, Bustamante RH, Branch GM, Eekhout S, Odendaal FJ (1992) A zoogeographic and functional approach to the selection of marine reserves on the west coast of South Africa. S Afr J Mar Sci 12:341-54

Emlet RB (1995) Developmental mode and species geographic range in regular sea urchins (Echinodermata: Echinoidea). Evolution 42:476-489

Excoffier L, Smouse PE, Quattro JM (1992) Analysis of molecular variance inferred from metric distances among DNA haplotypes: application to human mitochondrial DNA restriction data. Genetics 131:479-491

Felsenstein J (1985) Confidence limits on phylogenies: an approach using the bootstrap. Evolution 39:783-791

Folmer O, Black M, Hoeh R, Lutz R, Vrijenhoek RC (1994) DNA primers for amplification of mitochondrial cytochrome c oxidase subunit I from diverse metazoan invertebrates. Mol Mar Biol Biotechnol 3:294-299

Funk DJ, Omland KE (2003) Species-level paraphyly and polyphyly: frequency, causes, and consequences, with insights from animal mitochondrial DNA. Annu Rev Ecol Evol Syst 34:397-423

Gaines SD, Bertness MD (1992) Dispersal of juveniles and variable recruitment in sessile marine species. Nature 360: $579-580$

Goschen WS, Schumann EH (1990) Agulhas Current variabil- 
ity and inshore structures off the Cape Province, South Africa. J Geophys Res 95:667-678

Grant WS, Cherry MI (1985) Mytilus galloprovincialis Lmk. in South Africa. J Exp Mar Biol Ecol 90:179-191

Grant WS, Schneider AC, Leslie RW, Cherry MI (1992) Population genetics of the brown mussel Perna perna in southern Africa. J Exp Mar Biol Ecol 165:45-58

Griffiths CL, Hockey PAR, van Erkom Schurink C, Le Roux PJ (1992) Marine invasive aliens on South African shores: implications for community structure and trophic functioning. S Afr J Mar Sci 12:713-722

Harrison TD (2000) Preliminary assessment of the biogeography of the fishes in South African estuaries. Mar Freshw Res 53:479-490

Hasegawa M, Kishino K, Yano T (1985) Dating the humanape splitting by a molecular clock of mitochondrial DNA. J Mol Evol 22:160-174

Hebert PDN, Cywinska A, Ball SL, de Waard JR (2003) Biological identifications through DNA barcodes. Proc R Soc Lond B Biol Sci 270:313-321

Hedgecock D (1986) Is gene flow from pelagic larval dispersal important in the adaptation and evolution of marine invertebrates? Bull Mar Sci 39:550-564

Hilbish TJ, Mullinax A, Dolven SI, Meyer A, Koehn RH, Rawson PD (2000) Origin of the antitropical distribution pattern in marine mussels (Mytilus spp.): routes and timing of transequatorial migration. Mar Biol 136:69-77

Hockey PAR, van Erkom Schurink C (1992) The invasive biology of the mussel Mytilus galloprovincialis on the southern African coast. Trans R Soc S Afr 48:123-139

Johnson MS, Black R (1984) Pattern beneath the chaos: the effect of recruitment on genetic patchiness in an intertidal limpet. Evolution 38:1371-1383

Lee CE (1999) Rapid and repeated invasions of fresh water by the saltwater copepod Eurytemora affinis. Evolution 53: 1423-1434

Lee CE, Petersen CH (2003) Genotype by environment interaction for salinity tolerance in the freshwater invading copepod Eurytemora affinis. Phys Biochem Zool 76: 296-301

Lipscomb D, Platnick N, Wheeler Q (2003) The intellectual content of taxonomy: a comment on DNA taxonomy. Trends Ecol Evol 18:65-66

Lutjerharms JRE (1998) Coastal hydrography. In: Lubke R, de Moor I (eds) Eastern and southern Cape coasts. University of Cape Town Press and the Grahamstown Branch of The Wildlife and Environment Society of Southern Africa, p 50-61

Lutjerharms JRE (2004) The coastal oceans of south-eastern Africa. Sea 14:781-832

Mallet J, Willmott K (2003) Taxonomy: renaissance or Tower of Babel? Trends Ecol Evol 18:57-59

McQuaid CD, Phillips TE (2000) Limited wind-driven dispersal of intertidal mussel larvae: in situ evidence from the plankton and the spread of the invasive species Mytilus galloprovincialis in South Africa. Mar Ecol Prog Ser 201: 211-220

O'Toole MJ (1977) Investigations into some important fish larvae in the South East Atlantic in relation to hydrological environment. PhD thesis, University of Cape Town

Palumbi SR (1994) Genetic divergence, reproductive isolation, and marine speciation. Annu Rev Ecol Syst 25: $547-572$

Papakostas S, Triantafyllidis A, Kappas I, Abatzopoulos TJ (2005) The utility of the $16 \mathrm{~S}$ gene in investigating cryptic speciation within the Brachionus plicatilis species complex. Mar Biol 147:1129-1139
Peterson RG, Stramma L (1991) Upper-level circulation in the South Atlantic Ocean. Prog Oceanogr 26:1-73

Perron FE, Kohn AJ (1985) Larval dispersal and geographic distribution in coral reef gastropods of the genus Conus. Proc 5th Int Coral Reef Congr, Tahiti 5:95-100

Posada D, Crandall KA (1998) Model Test: testing the model of DNA substituion, Version 3.7. Bioinformatics 14:817-818

Potter IC, Beckley LE, Whitfield AK, Lenanton RCJ (1990) Comparison between the roles played by estuaries in the life cycles of fishes in temperate Western Australia and southern Africa. Environ Biol Fishes 28:143-178

Prochazka K (1994) Habitat partitioning in shallow-water cryptic ichthyofaunal communities in the western and south-western Cape, South Africa. PhD thesis, University of Cape Town

Quattro JM, Chase MR, Rex MA, Greig TW, Etter RJ (2001) Extreme mitochondrial DNA divergence within populations of the deep-sea gastropod Frigidoalvania brychia. Mar Biol 139:1107-1113

Reid D, Orlova MI (2002) Geological and evolutionary underpinnings for the success of Ponto-Caspian species invasions in the Baltic Sea and North American Great Lakes. Can J Fish Aquat Sci 59:1144-1158

Remerie T, Bourgois T, Peelaers D, Vierstraete A, Vanfleteren J, Vanreusel A (2006) Phylogeographic patterns in the mysid Mesopodopsis slabberi (Crustacea, Mysida) in Western Europe: evidence for high molecular diversity and cryptic speciation. Mar Biol 149:465-481

Reznick DN, Ghalambor CK (2001) The population ecology of contemporary adaptations: what empirical studies reveal about the conditions that promote adaptive evolution. Genetica 112:183-198

Ricciardi A, MacIsaac HG (2000) Recent mass invasion of the North American Great Lakes by Ponto-Caspian species. Trends Ecol Evol 15:62-65

Richmond RH (1987) Energetics, competency, and longdistance dispersal of planula larvae of the coral Pocillopora damicornis. Mar Biol 93:527-533

Rius M, McQuaid CD (2006) Wave action and competitive interaction between the invasive mussel Mytilus galloprovincialis and the indigenous Perna perna in South Africa. Mar Biol 150:69-78

Robinson TB, Griffiths CL, McQuaid CD, Rius M (2005) Marine alien species of South Africa - status and impacts. Afr J Mar Sci 27:297-306

Sale PF (1991) Reef fish communities: open nonequilibrial system. In: Sale PF (ed) The ecology of fishes on coral reefs. Academic Press, San Diego, CA, p 564-598

Scheltema RS (1989) Planktonic and non-planktonic development among prosobranch gastropods and its relationship to the geographic range of species. In: Ryland JS, Tyler PA (eds) Reproduction, genetics, and distributions of marine organisms. Olsen \& Olsen, Fredensborg, Denmark, p 183-188

Schneider S, Roessli D, Excoffier L (2000) ARLEQUIN: a software for population genetics data analysis, Ver. 2.0. Department of Anthropology, University of Geneva, Switzerland

Shanks A (1995) Mechanisms of cross-shelf dispersal of larval invertebrates. In: McEdward L (ed) Ecology of marine invertebrate larvae. CRC Press, Boca Raton, FL, p 323-368

Shanks AL, Brink L (2005) Upwelling, downwelling, and cross-shelf transport of bivalve larvae: test of a hypothesis. Mar Ecol Prog Ser 302:1-12

Shannon LV (1985) The Benguela ecosystem. Part I. Evolution of the Benguela, physical features and processes. Oceanogr Mar Biol Annu Rev 23:105-182 
Slatkin M (1993) Isolation by distance in equilibrium and nonequilibrium populations. Evolution 47:264-279

Stephenson TA, Stephenson A (1972) Life between tidemarks on rocky shores. WH Freeman, San Francisco

Swofford DL (2002) PAUP*. Phylogenetic analysis using parsimony ( ${ }^{*}$ and other methods), Ver. 4. Sinauer Associates, Sunderland, MA

Tamura K, Nei M (1993) Estimation of the number of nucleotide substitutions in the control region of mitochondrial DNA in humans and chimpanzees. Mol Biol Evol 10:512-526

Tarjuelo I, Posada D, Crandall KA, Pascual M, Turon X (2001) Cryptic species of Clavelina (Ascidiacea) in two different habitats: harbours and rocky littoral zones in the northwest Mediterranean. Mar Biol 139:455-462

Thackeray JF, Herbert RS (1991) Environmental indices from planktonic foraminifera in Late Holocene sediments off Walvis Bay. S Afr J Sci 87:611-618

Editorial responsibility: Otto Kinne (Editor-in-Chief), Oldendorf/Luhe, Germany
Todd CD (1998) Larval supply and recruitment of benthic invertebrates: do larvae always disperse as much as we believe? Hydrobiologia 375/376:1-21

Turpie JK, Beckley LE, Katua SM (2000) Biogeography and the selection of priority areas for conservation of South African coastal fishes. Biol Conserv 92:59-72

Van Erkom Schurink C, Griffiths CL (1990) Marine mussels of southern Africa - their distribution, standing stocks, exploitation and culture. J Shellfish Res 9:75-85

Wedepohl PM, Lurjeharms JRE, Meeuwis JM (2000) Surface drift in the south-east Atlantic Ocean. S Afr J Mar Sci 22:71-79

Will K, Rubinoff D (2004) Myth of the molecule: DNA barcodes for species cannot replace morphology for identification and classification. Cladistics 20:47-55

Wolff WJ (2000) Recent human-induced invasions of fresh waters by saltwater animals? Aquat Ecol 34:319-321

Submitted: June 7, 2006; Accepted: October 31, 2006 Proofs received from author(s): April 27, 2007 